\title{
PENGARUH KUALITAS LAYANAN, KEPERCAYAAN DAN KOMITMEN TERHADAP LOYALITAS KONSUMEN PADA CV.SHOWROOM YULIA MOTOR
}

\author{
Parubahan Pohan $^{1}$, Elida F.S Simanjorang ${ }^{2}$ \\ ${ }^{1}$ Alumni STIE Labuhanbatu \\ ${ }^{2}$ Dosen STIE Labuhanbatu
}

\begin{abstract}
ABSTRAK
Tujuan penelitian ini adalah: 1) Untuk mengetahui pengaruh kualitas layanan terhadap loyalitas konsumen pada CV. Showroom Yulia Motor, 2) untuk mengetahui pengaruh kepercayaan terhadap loyalitas konsumen pada CV. Showroom Yulia Motor dan untuk mengetahui pengaruh komitmen terhadap loyalitas konsumen pada CV. Showroom Yulia Motor.Hipotesis penelitian adalah variabel kualitas layanan berpengaruh signifikan terhadap loyalitas konsumen pada CV. Showroom Yulia Motor, variabel kepercayaan berpengaruh signifikan terhadap loyalitas konsumen pada CV. Showroom Yulia Motor dan variabel komitmen berpengaruh terhadap loyalitas konsumen pada CV. Showroom Yulia Motor.Hasil penelitian menunjukkan bahwa: 1) kualitas layanan berpengaruh positif dan signifikan terhadap loyalitas konsumen pada CV. Showroom Yulia Motor, kepercayaan berpengaruh positif dan signifikan terhadap loyalitas konsumen pada CV. Showroom Yulia Motor dan komitmen berpengaruh positif dan signifikan terhadap loyalitas konsumen pada CV. Showroom Yulia Motor.
\end{abstract}

Kata kunci: Kualitas Layanan, Kepercayaan, Komitmen, Loyalitas Konsumen. 


\section{PENDAHULUAN}

Perkembangan pasar yang begitu pesat telah mendorong perusahaan untukmencari celah guna meningkatkan loyalitas pelanggan yang tercermin pada keuntunganyang diraih perusahaan tersebut. Salah satu strategi yangdigunakan dalam mencapai loyalitas pelanggan adalah strategi pemasaran berdasarkemitraan. Pemasaran berdasarkan kemitraan mengindikasikan adanya investasi bagisuatu perusahaan dalam membangun ikatan jangka panjang dengan konsumen secaraindividu. Strategi ini tidak hanya bertujuan mendapatkan konsumen yang loyal, namunjuga mampu menciptakan keunggulan bersaing berkelanjutan.

Lebih lanjut dinyatakan bahwa argumen yang melatarbelakangi pernyataan tersebutadalah karena kemampuaan strategi tersebut dalam mengembangkan aset yang intangibleyang sukar ditiru oleh pesaing.Dari berbagai penelitian yang berkaitan dengan loyalitas pelanggan, ternyata pemasaran berdasarkan kemitraan kurang mendapatkan perhatian parapeneliti sebagai variabel yang menentukan tinggi rendahnya loyalitas pelanggan.

Bahwa pemasaranberdasarkan kemitraan merupakan prediktor terbaik dibandingkan dengan service quality(kualitas layanan) yang telah terlebih dahulu diteliti oleh para ahli sebelumnya. Pemasaran berdasarkan kemitraan dibangun darivariabel komitmen dan kepercayaan. Dengan demikian perlu kiranya bagi peneliti mengkaji lebih jauh tentang pengaruh komitmen dan kepercayaan serta kualitas layanan terhadap loyalitas pelanggan.

Loyalitas pelanggan yang terlihat pada CV. Showroom Yulia motor masih kuranga. Terlihat dari berkurang jumlah konsumen yang datang, hal ini pula yang dapat menjadi permasalahan oleh perusahaan, agar konsumen dapat mempercayai produk yang ditawarkan dan melakukan pembelian ulang pada perusahaan tersebut, banyak perusahaan mengandalkan kepuasan konsumen sebagai jaminan keberhasilan di kemudian hari tetapi kemudian kecewa mendapati bahwa para konsumennya yang merasa puas dapat membeli produk pesaing tanpa ragu-ragu

Konsep kualitas layanan telah menjadi faktor yang sangat dominan terhadapkeberhasilan organisasi. Pelanggan yang puas, terhadap barang / jasa maka akandengan mudah membentuk niatnya dalam membeli ulang dan berkecenderunganakan mempersering pembelian barang / jasa serta semakin loyal terhadap barang /jasa tersebut, pada akhirnya terbentuklah hubungan jangka panjang antara konsumen dengan produsen tersebut.

Terdapat beberapa permasalahan bagi perusahaan tentang pentingnya mempertahankan loyalitas pelanggan. Imbalan dari loyalitas yang bersifat jangka panjang dan kumulatif. Jadi semakin lama loyalitas seorang konsumen, semakin besar laba yang dapat diperoleh perusahaan dari seorang konsumen.

Untuk mempertahankan loyalitaspelanggan tidak hanya dibutuhkankepuasan, melainkan lebih dari itu adalah menjaga kualitas layanan, kepercayaan dan komitmen pelanggan yangmerupakan kunci dari relationship marketing. Loyalitas pelanggan adalah besarnya konsumsidan frekuensi pembelian yang dilakukan olehseorang konsumen terhadap suatu perusahaan(took retail). 
Kehadiran perusahan-perusahaan baru membuat kualitas layanan pada CV. Showroom Yulia Motor menurun. Hal ini terlihat dari berkurangnya jumlah konsumen yang datang. Karyawan yang kurang ramah dalam memberikan pelayanan terhadap konsumen mengakibatkan pelanggan berkurang satu demi satu dan berpindah menjadi pelanggan di perusahaan yang baru.

Selain kualitas layanan yang kurang dirasakan oleh konsumen, faktor kepercayaan terhadap CV. Showroom Yulia Motor juga terlihat berkurang, hal ini disebabkan mulai karyawan kurang terbuka terhadap pekerjaannya, kurang dapat mengatasi masalah yang dihadapi konsumen, pelayanannya mulai lambat, dan adanya keinginan untuk mencari tempat lain yang dirasa memiliki keunggulan.

Selain itu beberapa investor yang menjalin kerja sama dengan CV. Showroom Yulia Motor mulai berkurang dan memutuskan hubungan kerjasamanya dengan CV. Showroom Yulia Motor. Hal ini dapat terlihat dari perbedaan komitmen diantara para investor dengan CV. Showroom Yulia Motor. Sebab CV. Showroom Yulia Motor dianggap kurang mengembangkan strategi relationship marketing.

Olehkarena itu penulis mencoba meneliti pengaruhkualitas layanan, kepercayaan dan komitmenterhadap loyalitas pelanggan Berdasarkan paparan diatas maka penulis tertarik untuk membuat penelitian dengan judul Pengaruh kualitas layanan, kepercayaan dan komitmen terhadap loyalitas konsumen pada CV. Showroom Yulia Motor.

\section{TINJAUAN PUSTAKA}

\section{Kualitas Layanan}

Kualitas pelayanan pada umumnya dipandang sebagai hasil keseluruhan sistempelayanan yang diterima konsumen, dan pada prinsipnya, bahwa kualitas pelayananberfokus pada upaya pemenuhan kebutuhan dan keinginan pelanggan, serta adanya tekaduntuk memberikan pelayanan sesuai dengan harapan pelanggan. Duffy (2006), berpendapat bahwa kualitas pelayanan berkaitan dengan persepsi pelanggan terhadappelayanan yang akan diterima dari perusahaan. Lebih jauh Duffy (2006) menambahkan bahwakualitas pelayanan dapat diukur melalui perbedaan antara persepsi terhadap kualitaspelayanan yang diterimanya, dengan harapan pelanggan terhadap pelayanan yang akanditerimanya.

Sedangkan menurut Kotler (2008), kualitas pelayanan pada prinsipnyamengandung pengertian bahwa kualitas harus dimulai dari kebutuhan dan keinginanpelanggan, dan berakhir pada persepsi pelanggan. Hal ini berarti bahwa citra kualitasyang baik bukan dilihat dari persepsi perusahaan, melainkan berdasarkan pada persepsipelanggan. Persepsi pelanggan terhadap kualitas pelayanan, merupakan penilaian yangmenyeluruh atas keunggulan suatu produk atau jasa. Kualitas pelayanan dibentuk olehperbandingan antara kondisi ideal dan persepsi dari kinerja dimensi kualitas (Oliver, 2006). Sehingga dapat dikatakan bahwa kualitas produk atau jasa merupakan penilaianpelanggan terhadap kesempurnaan performansi atas produk atau jasa yang dikonsumsi(Mowen, 2006). 


\section{Kepercayaan}

Menurut Moorman (2006), kepercayaan didefinisikan sebagaikemauan untuk menyandarkan diri pada hubungan dengan partnernya berlandaskan ataskeyakinan. Rotter's (2006) yang menyatakan bahwa kepercayaan merupakan harapan umum yangdimiliki individu bahwa kata-kata yang muncul dari pihak lainnya dapat diandalkan.

Kepercayaan adalah percaya dan memiliki keyakinan terhadap partner dalam hubungan(Moorman 2006) karena memiliki kredibilitas dan kebajikan. Kredibilitas menunjukkan kepercayaan yang didapat dari pihak lainkarena memiliki keahlian yang dikehendaki untuk melakukan suatu tugas, dankepercayaan yang didapat karena melakukan cara yang baik kepada pihak lain dalamsuatu hubungan. Johnson (2007) menyatakan bahwa keterpercayaanmuncul dari kemampuan untuk membuktikan sesuatu, reliabilitas danintensionalitas.

\section{Komitmen}

Shoemaker (2006) mengungkapkan bahwa dalam perkembanganterbaru, industri bisnis kini lebih banyak menggunakan pendekatan relationshipmarketing dibanding pendekatan transaksional. Hal tersebut patut dipahami mengingatpendekatan transaksional memiliki banyak kelemahan, antara lain pendekatan tersebutmudah ditiru oleh pesaing. Sedangkan pendekatan relationship marketing akanmendapatkan pelanggan yang loyal, dimana hal tersebut tidak mudah ditiru oleh pesaing.

Pemahaman yang pertama kali tentang relationship marketing terletak padaperbedaannya dengan discrete transaction. Discrete transaction menekankan pada suatupola hubungan jangka pendek. Sedangkan pada relationship transaction lebihmenekankan pada pola hubungan jangka panjang (Gronhaug, et al, 2007).

\section{Loyalitas konsumen}

Tjiptono (2011) menyatakan bahwa loyalitas konsumen adalah komitmen konsumen terhadap suatu merek, jasa atau pemasok (perusahaan),berdasarkan sikap yang sangat positif dan tercermin dalam pembelian ulang yang konsisten.

Menurut Wahyu Nugroho (2006) loyalitas pelanggan didefinisikan sebagai suatu ukuran kesetiaan dari pelanggan dalam menggunakan suatu merek produk atau merek jasa pada kurun waktu tertentu pada situasi dimana banyak pilihan produk ataupun jasa yang dapat memenuhi kebutuhannya dan pelanggan memiliki kemampuan mendapatkannya.Loyalitas menggambarkan keinginan pelanggan untuk terus berlangganan dalam jangka waktu yang panjang, melakukan pembelian, menggunakan produk atau jasa secara berulang dan merekomendasikanperusahaan terhadap kolega atau orang lain.

Utomo (2006) memberikandefinisi mengenai Loyalitas (loytalitas jasa), yaitu derajat sejauhmana seorang konsumen menunjukkan perilaku pembelianberulang dari suatu penyedia jasa, memiliki suatu desposisi ataukecenderungan sikap positif terhadap penyedia jasa, dan hanyamempertimbangkan untuk menggunakan penyedia jasa ini padasaat muncul kebutuhan untuk memakai jasa ini. Dari definisi yangdisampaikan Gramer dan Brown, konsumen yang loyal tidak hanyaseorang pembeli yang melakukan 
pembelian berulang, tetapi jugamempertahankan sikap positif terhadap penyedia jasa.

\section{METODE PENELITIAN}

\section{Populasi dan Sampel}

Populasi adalah wilayah generalisasi yang terdiri atas objek atau subjek yangmempunyai kualitas dan karakteristik tertentu yang ditetapkan oleh peneliti untukdipelajari kemudian ditarik kesimpulannya. (Sugiono, 2007).Populasi dalam penelitian ini adalah masyarakat yang berkunjung ke CV. Showroom Yulia Motor.

\section{2, Sampel penelitian}

Sampel adalah bagian dari jumlah dan karakteristik yang dimiliki oleh populasi.(Sugiono, 2007). Penentuan jumlah sampel ditentukan dengan menggunakan beberapa metode antara lain dengan menggunakan rumus sebagai berikut Widiyanto (2008).

$$
\begin{gathered}
n=\frac{Z^{2}}{4(M o e)^{2}} \\
n=\frac{1,98^{2}}{4(0,1)^{2}}
\end{gathered}
$$

$n=98,01$

Dimana :

$n \quad$ : Jumlah sampel

$\mathrm{Z} \quad$ : Tingkat keyakinan yang dibutuhkan dalam penentuan sampel $95 \%$ pada penentuan ini $Z$ pada $\alpha=0,5$ adalah 1,98

Moe : Margin of Error, yaitu tingkat kesalahan maksimal yang dapat ditoreransi, ditentukan sebesar $10 \%$

Dari hasil perhitungan sampel diatas maka jumlah sampel dalam penelitian ini sebanyak 98 responden.

\section{Analisis Data}

\section{Analisis Regresi Linier Berganda}

Dalam menganalisis data yang di peroleh penulismenggunakan metode regresilinier berganda, yaitu menganalisis tentang hubungan antara variabel dependen dengadua variabel atau lebih variabel dependen. (Arikunto, 2007)Untuk mengetahui besarnya pengaruh kualitas jasa dan harga terhadap loyalitas konsumen pada Hotel Permata Land Rantauprapat digunakanrumus regresi linier berganda sebagai berikut :

Dimana :

$$
Y=a+b_{1} X_{1}+b_{2} X_{2}+b_{3} X_{3}+e
$$

Keterangan :

$\mathrm{Y}=$ Variabel terikat (dependen), Loyalitas konsumen

a = Nilai Konstanta

$\mathrm{b} \quad=$ Nilai Koefisien Regresi 
$\mathrm{X}_{1}=$ Variabel Bebas(independen), Kualitas layanan

$\mathrm{X}_{2}=$ Variabel Bebas (independen), Kepercayaan

$\mathrm{X}_{3}=$ Variabel Bebas (independen), Komitmen

$\mathrm{e} \quad=$ Sistem error (faktor pengganggu)

Pengujian hipotesis

Pengujian hipotesis dalam penelitian ini adalah menggunakan regresi berganda :

\section{Hasil Analisis Regresi Berganda}

Analisis ini digunakan untuk mengetahui pengaruh variabel bebas (kualitas layanan, kepercayaan dan komitmen) terhadap variabel terikat (loyalitas konsumen). Hasil analisis regresi sebagai berikut:

Tabel 1

\section{Hasil Analisis Regresi Linear Berganda}

\begin{tabular}{|c|c|c|c|c|c|}
\hline \multicolumn{6}{|c|}{ Coefficients $^{\mathbf{a}}$} \\
\hline \multirow[b]{2}{*}{ odel } & \multicolumn{2}{|c|}{$\begin{array}{l}\text { Unstandard } \\
\text { ized } \\
\text { Coefficient } \\
\text { s }\end{array}$} & $\begin{array}{l}\text { Standar } \\
\text { dized } \\
\text { Coeffici } \\
\text { ents }\end{array}$ & \multirow[b]{2}{*}{$\mathrm{t}$} & \multirow[b]{2}{*}{ Sig. } \\
\hline & B & $\begin{array}{l}\text { Std. } \\
\text { Erro } \\
\text { r }\end{array}$ & Beta & & \\
\hline 1 (Constant & 2835 & 1,97 & & 1,43 &, 15 \\
\hline ) & 2,055 & 2 & & 8 & 4 \\
\hline Kualitas & 203 & 057 & 275 & 3,58 & ,00 \\
\hline layanan & & & & 3 & 1 \\
\hline Kepercay & 266 & 091 & 218 & 2,92 & ,00 \\
\hline aan & & & & 5 & 4 \\
\hline Komitme & ,419 & ,067 & ,478 & 6,22 & ,00 \\
\hline & & & & & \\
\hline
\end{tabular}

a. Dependent Variable: Loyalitas konsumen

\section{Sumber: Data diolah,2016}

Hasil pengolahan komputer dapat diketahui persamaan koefisien regresi linier berganda yang diperoleh sebagai berikut:

$$
Y=2,835+0,203 X_{1}+0,266 X_{2}+0,419 X_{3}
$$

Persamaan regresi berganda tersebut dijelaskan sebagai berikut:

1. Nilai konstanta 2,835 memberi arti bahwa apabila kualitas layanan $\left(\mathrm{X}_{1}\right)$, kepercayaan $\left(\mathrm{X}_{2}\right)$ dan komitmen $\left(\mathrm{X}_{3}\right)$ sama-sama tetap pada nilai nol atau konstan, maka loyalitas pelanggan (Y) yang dihasilkan bernilai 2,835. 
2. Kualitas layanan berpengaruh positif dan signifikan terhadap loyalitas konsumen dengan koefisien regresi sebesar 0,203. Artinya apabila kualitas layanan naik 0,203 maka loyalitas konsumen juga akan naik sebesar 0,203.

3. Kepercayaan berpengaruh positif dan signifikan terhadap loyalitas konsumen dengan koefisien regresi sebesar 0,266. Artinya apabila kepercayaan naik 0,266 maka loyalitas konsumen juga akan naik sebesar0,266.

4. Komitmen berpengaruh positif dan signifikan terhadap loyalitas konsumen dengan koefisien regresi sebesar 0,419. Artinya apabila komitmen naik 0,419 maka loyalitas konsumen juga akan naik sebesar0,419.

\section{Koefisien Determinasi $\left(\mathbf{R}^{\mathbf{2}}\right)$}

Analisis ini digunakan untuk mengetahui seberapa besar sumbangan atau pengaruh yang diberikan variabel bebas terhadap variabel terikat yang ditunjukkan dengan persentase. Hasil koefisien determinasi sebagai berikut:

Tabel 2

Hasil Koefisien Determinasi $\left(\mathbf{R}^{2}\right)$ Model Summaryb

\begin{tabular}{|c|c|c|c|c|}
\hline Model & $\mathrm{R}$ & $\begin{array}{c}\mathrm{R} \\
\text { Square }\end{array}$ & $\begin{array}{c}\text { Adjust } \\
\text { ed R } \\
\text { Square }\end{array}$ & $\begin{array}{l}\text { Std. } \\
\text { Error of } \\
\text { the } \\
\text { Estimat } \\
\mathrm{e}\end{array}$ \\
\hline 1 &, $733^{\mathrm{a}}$ &, 537 &, 522 & 1,197 \\
\hline
\end{tabular}

a. Predictors: (Constant), Komitmen,

Kepercayaan, Kualitas layanan

b. Dependent Variable: Loyalitas konsumen

\section{Sumber: Data diolah,2016}

Nilai koefisien determinasi $\left(\mathrm{R}^{2}\right)$ menunjukkan besarnya kontribusi pengaruh variabel bebas terhadap variabel terikat. Hasil perhitungan yang dihasilkan pada tabel 4.15 diatas menunjukkan nilai $\mathrm{R}^{2}=0,537$. Hal ini berarti menunjukkan bahwa sebesar 53,70 \% loyalitas konsumen dipengaruhi oleh kualitas layanan, kepercayaan dan komitmen sedangkan sisanya sebesar 46,30\% dipengaruhi oleh variabel lain yang tidak diteliti.

\section{Pengujian Hipotesis}

Berdasarkan data penelitian yang dikumpul baik untuk variabel terikat (loyalitas pelanggan) maupun variabel bebas (kualitas layanan, kepercayaan dan komitmen) yang diolah dengan bantuan program spss versi 20.0 uji signifikan simultan (uji-f) dan uji signifikan parsial (uji-t) sebagai berikut:

\section{Uji Hipotesis Secara Parsial (Uji t)}


Analisis ini digunakan untuk mengetahui tingkat signifikansi pengaruh variabel bebas terhadap variabel terikat secara parsial. Hasil uji t sebagai berikut:

Tabel 3

Hasil Uji t

\section{Coefficients $^{\mathrm{a}}$}

\begin{tabular}{|c|c|c|c|c|c|}
\hline \multirow[b]{2}{*}{ Model } & \multicolumn{2}{|c|}{$\begin{array}{l}\text { Unstandard } \\
\text { ized } \\
\text { Coefficient } \\
\text { s }\end{array}$} & \multirow{2}{*}{$\begin{array}{c}\begin{array}{c}\text { Standar } \\
\text { dized } \\
\text { Coeffici } \\
\text { ents }\end{array} \\
\text { Beta }\end{array}$} & \multirow[b]{2}{*}{$\mathrm{t}$} & \multirow[b]{2}{*}{$\begin{array}{l}\mathrm{Si} \\
\text { g. }\end{array}$} \\
\hline & B & $\begin{array}{l}\text { Std. } \\
\text { Error }\end{array}$ & & & \\
\hline 1 (Constant) & $\begin{array}{c}2,83 \\
5\end{array}$ & 1,972 & & $\begin{array}{c}1,43 \\
8\end{array}$ & $\begin{array}{l}, 1 \\
54\end{array}$ \\
\hline $\begin{array}{l}\text { Kualitas } \\
\text { layanan }\end{array}$ & ,203 & ,057 & ,275 & $\begin{array}{c}3,58 \\
3\end{array}$ & $\begin{array}{l}, 0 \\
01\end{array}$ \\
\hline $\begin{array}{l}\text { Kepercayaa } \\
\mathrm{n}\end{array}$ & ,266 & ,091 & ,218 & $\begin{array}{c}2,92 \\
5\end{array}$ & $\begin{array}{l}, 0 \\
04\end{array}$ \\
\hline Komitmen & ,419 & ,067 & ,478 & $\begin{array}{c}6,22 \\
1\end{array}$ & $\begin{array}{l}, 0 \\
00\end{array}$ \\
\hline
\end{tabular}

a. Dependent Variable: Loyalitas konsumen

Sumber: Data diolah,2016

1. Pengujian hipotesis kualitas layanan $\left(\mathrm{X}_{1}\right)$ terhadap loyalitas konsumen $(\mathrm{Y})$.

Hasil perhitungan diperoleh nilai $t$ hitung $(3,583)>$ dari $t$ tabel $(1,665)$ maka Ho ditolak dan Ha diterima, sehingga variabel kualitas layanan berpengaruh secara signifikan terhadap loyalitas konsumen pada CV. Showroom Yulia Motor.

2. Pengujian hipotesis kepercayaan $\left(\mathrm{X}_{2}\right)$ terhadap loyalitas konsumen $(\mathrm{Y})$. Hasil perhitungan diperoleh nilai t hitung $(2,925)>$ dari $t$ tabel $(1,665)$ maka Ho ditolak dan Ha diterima, sehingga variabel kepercayaan berpengaruh secara signifikan terhadap loyalitas konsumen pada CV. Showroom Yulia Motor.

3. Pengujian hipotesis komitmen $\left(\mathrm{X}_{2}\right)$ terhadap loyalitas konsumen $(\mathrm{Y})$. Hasil perhitungan diperoleh nilai t hitung $(6,221)>$ dari $t$ tabel $(1,665)$ maka Ho ditolak dan Ha diterima, sehingga variabel komitmen berpengaruh secara signifikan terhadap loyalitas konsumen pada CV. Showroom Yulia Motor.

\section{Uji Hipotesis Secara Simultan (Uji F)}


Uji F digunakan untuk mengetahui signifikans pengaruh variabel bebas secara bersama-sama terhadap variabel terikat. Hasil uji F sebagai berikut:

\section{Tabel 4}

Hasil Uji F

ANOVA $^{a}$

\begin{tabular}{|c|c|c|c|c|c|}
\hline Model & $\begin{array}{c}\text { Sum } \\
\text { of } \\
\text { Square } \\
\text { s }\end{array}$ & Df & $\begin{array}{c}\text { Mean } \\
\text { Squar } \\
\text { e }\end{array}$ & $\mathrm{F}$ & $\begin{array}{c}\text { Sig } \\
.\end{array}$ \\
\hline 1 Regressi & $\begin{array}{r}155,87 \\
4\end{array}$ & 3 & $\begin{array}{r}51,95 \\
8\end{array}$ & $\begin{array}{r}36,28 \\
1\end{array}$ & $\begin{array}{r}, 00 \\
0^{\mathrm{b}}\end{array}$ \\
\hline Residual & $\begin{array}{r}134,61 \\
6\end{array}$ & 94 & 1,432 & & \\
\hline Total & $\begin{array}{r}290,49 \\
0\end{array}$ & 97 & & & \\
\hline
\end{tabular}

a. Dependent Variable: Loyalitas konsumen

b. Predictors: (Constant), Komitmen,

Kepercayaan, Kualitas layanan

\section{Sumber: Data diolah,2016}

Nilai F hitung $(36,281)>$ dari nilai $F$ tabel $(2,47)$ dengan nilai signifikan $0,000<$ 0,05 maka Ho ditolak sehingga ada pengaruh yang signifikan kualitas layanan, kepercayaan dan komitmen secara simultan terhadap loyalitas konsumen pada CV. Showroom Yulia Motor.

\section{Pembahasan}

Hasil pengujian koefisien kualitas layanan terhadap loyalitas konsumen pada CV. Showroom Yulia Motor memiliki jalur positif sebesar 0,203 yang berarti semakin baik kualitas layanan akan meningkatkan loyalitas konsumen. Nilai probabilitas (p) sebesar 0,000 yang berarti ada pengaruh signifikan kualitas layanan terhadap loyalitas konsumen pada CV. Showroom Yulia Motor.

Hasil pengujian koefisien kepercayaan terhadap loyalitas konsumen pada CV. Showroom Yulia Motor memiliki jalur positif sebesar 0,266 yang berarti semakin baik kepercayaan akan meningkatkan loyalitas konsumen. Nilai probabilitas (p) sebesar 0,000 yang berarti ada pengaruh signifikan kepercayaan terhadap loyalitas konsumen pada CV. Showroom Yulia Motor.

Hasil pengujian koefisien komitmen terhadap loyalitas konsumen pada CV. Showroom Yulia Motor memiliki jalur positif sebesar 0,419 yang berarti semakin baik komitmen akan meningkatkan loyalitas konsumen. Nilai probabilitas (p) sebesar 0,000 yang berarti ada pengaruh signifikan komitmen terhadap loyalitas konsumen pada CV. Showroom Yulia Motor. 


\section{KESIMPULAN DAN SARAN}

\section{Kesimpulan}

Hasil penelitian dan pembahasan tentang Pengaruh kualitas layanan, kepercayaan dan komitmen terhadap loyalitas konsumen pada CV. Showroom Yulia Motor, maka penulis mengambil kesimpulan :

1. Secara parsial kualitas layanan memiliki pengaruh positif terhadap loyalitas konsumen pada CV. Showroom Yulia Motor sebesar 0,203 yang berarti semakin baik kualitas layanan akan semakin baik loyalitas konsumen.

2. Secara parsial kepercayaan memiliki pengaruh positif terhadap loyalitas konsumen pada CV. Showroom Yulia Motor sebesar 0,266 yang berarti semakin baik kepercayaan akan meningkatkan loyalitas konsumen.

3. Secara parsial komitmen memiliki pengaruh positif terhadap loyalitas konsumen pada CV. Showroom Yulia Motor sebesar 0,419 yang berarti semakin baik komitmen akan meningkatkan loyalitas konsumen.

4. Secara simultan kualitas layanan, kepercayaan dan komitmen berpengaruh positif dan signifikan terhadap loyalitas konsumen pada CV. Showroom Yulia Motor.

\section{Saran}

Berdasarkan temuan hasil penelitian yang telah dikemukakan sebelumnya, maka untuk meningkatkan keputusan pembelian adalah sebagai berikut:

1. Diharapkan untuk meninkatkan kualitas layanan terhadap konsumen, dengan melakukan senyum yang ramah dan tutur sapa yang sopan dan dapat menyakinkan konsumen

2. Diharapkan untuk meningkatkan kepercayaan terhadap konsumen dengan cara memberikan informasi yang benar dan sesuai dengan kualitas produk yang diberikan sehingga konsumen percaya bahwa produk yang ditawarkan itu asli atau palsu.

3. Diharapkan untuk meningkatkan komitmen yang baik diantara pelanggan dengan CV. Showroom Yulia Motor dan menjalin kerja sama yang baik dengan menjunjung tinggi komitmen yang telah disepakati bersama.

4. Mengingat variabel bebas dalam penelitian ini merupakan hal yang sangat penting dalam mempengaruhi loyalitas konsumen diharapkan hasil penelitian ini dapat dipakai sebagai acuan bagi peneliti selanjutnya untuk mengembangkan penelitian ini dengan mempertimbangkan variabelvariabel lain yang merupakan variabel lain diluar variabel kualitas layanan, kepercayaan dan komitmen yang tercantum dalam penelitian. 


\section{DAFTAR PUSTAKA}

Arikunto, Suharsimi. 2007. Manajemen penelitian. Jakarta : Rineka Cipta.

Bowen, J, and Shoemaker, S (2006), Loyalty: A Strategy Commitment, Cornell H.R.A,Quarterly, Vol 2. pp. 12-25.

Duffy Jo Ann M And Alice A Katehand (2006), Examining The Role of Servise Satisfaction, Journal of ManagementIssues, Vol X Numller 2, Hal 240 255.

Ghozali, Imam. 2006. "Aplikasi Analisis Multivariate Dengan Program SPSS".Semarang : Badan Penerbit Undip.

Garbarino, Ellen, Mrk S Johnson, 2006, The Different Roles of Satisfaction, Trust, and Commitment in Customer Relationship, Journal of Marketing, vol. 63 (April), pp $70-87$.

Ibnu, Widiyanto, 2008. Pointers : Metodologi Penelitian. Semarang: BP Undip

Kotler, Philip dan Gary Amstrong,2008, Prinsip-PrinsipPemasaran, Jilid 1, EdisiKeduabelas, Erlangga, Jakarta.

Moorman, Christin, Gerald Zaltman and Rohit Desphande (2006) RelationshipsBeetwen Provider and Users of Market Researt : The Dinamics Of TrustWithim and Between Organizations, Journal Marketing Research, vol XXIX, 314-28

Mowen, J. Dan Minor, M 2006. Perilaku Konsumen. Jakarta: Erlangga

Oliver, Richard L, 2006. Satisfaction, A Behavioral Perspective on The Custumer, Mc Graw-Hill Companies inc: New York

Parasuraman, A. Valerie, A Zeuthaml and Leonard L Berry (2006) A Multiple ItemScale for Measuring Customer Perception or Future Research, Journal ofMarketing, Vol. 49 No.1

Sugiyono. 2007. “Metode Penelitian Kuantitatif Kualitatif dan R\&D”. Bandung: Alfabeta

Sutisna., 2007, Perilaku Konsumen \& Komunikasi Pemasaran, Cetakan Ketiga, Bandung: PT Remaja Posdakarya.

Tjiptono, Fandy \& Gregorius Chandra. 2011. Service, Quality \& Satisfaction Edisi 3. Yogyakarta: ANDI

Utomo, Priyanto Doyo, 2006, Analisis Terhadap Faktor-Faktor Yang MempengaruhiLoyalitas Konsumen Pada Operator Telepon Seluler. Thesis: Universitas GadjahMada.

Wahyu Nugroho, “Loyalitas Konsumen”, artikel ini diakses pada 30 Januari 2014 dari http://wnugros.blogspot.com/2005/11/loyalitas-konsumen.html Jakarta. 